\title{
Neoplastic and Malignant Lymphedema after Breast Cancer
}

\author{
Patrícia Vieira Guedes Figueira* \\ Physiotherapist, Breast Diseases Division, Brazil \\ *Corresponding author: Patrícia Vieira Guedes Figueira, Physiotherapist, Breast Diseases Division, Brazil
}

Submission: 泟 February 20, 2019; Published: 海 February 25, 2019

Keywords: Modeling; Phototherapy; Kinetic; Anti-cancer; Singlet oxygen; Efficacy

\section{Opinion}

Lymphedema is one of the most feared oncological postoperative complications. Its occurrence is multifactorial, which means that it depends on several circumstances to develop [1]:

A. Lymphadenectomy

B. Radiotherapy in lymph nodal chain

C. Administration of peripheral chemotherapy on the same side of the injure.

\section{Older age \\ E. Excessive weight \\ F. Among others}

Despite all that fear, it is classified as benign complication in the great majority of the cases, and it has an available treatment. The Complex Decongestive Therapy (CDT) is the main treatment and it combines [2-4]:
A. Manual Lymph Drainage
B. Compression therapy (Bandaging, wraps)
C. Prescription for medical compression garments
D. Exercise
E. Skin Care

However, there are other two types of lymphedema that are not classified as benign, the neoplastic lymphedema and the malignant lymphedema. Their characteristics are similar, but the anatomopathological aspects vary between carcinoma and sarcoma, respectively. Their onset is sudden, with diffuse pain, and the presence of tumoral invasion and compression of nerve roots. The skin presents a cyanotic or reddish aspect, alteration in temperature and palpable lymph nodes, and in some cases may present collateral circulation and carcinogenic ulcer. Diminution in range of motion and muscle strength, and postural alterations may also occur $[2,5,6]$. (Table 1) Like everything within physiotherapy, an evaluation and differentiation of each type of lymphedema is essential to determine the best treatment. In neoplastic or malignant lymphedema cases, chemotherapy is usually administered concomitantly, and it is the physiotherapist with a specialization in oncology responsibility to seek for more independence, functionality, quality and comfort in patients' survival. Other alternative treatments may aid the complex physical therapy, as acupuncture, manual therapy, slings, among others. The adoption of the best approach is based on the patients' response to the treatments.

\section{Table 1:}

\begin{tabular}{|c|c|}
\hline Neoplastic Lymphedema & Malignant Lymphedema \\
\hline $\begin{array}{c}\text { It originates from tumoral com- } \\
\text { pression on the lymphatic system, } \\
\text { infiltration of the tumor in lym- } \\
\text { phatic vessels or lymph nodes }\end{array}$ & $\begin{array}{c}\text { It originates from the lymph- } \\
\text { edema's chronicity and chronic } \\
\text { inflammation. }\end{array}$ \\
\hline $\begin{array}{c}\text { Carcinoma's compression or inva- } \\
\text { sion in the lymphatic structures }\end{array}$ & $\begin{array}{c}\text { Lymphatic vascular endothelium } \\
\text { sarcoma or lymphangiosarcoma or } \\
\text { Stewart-Treves Syndrome }\end{array}$ \\
\hline
\end{tabular}

\section{References}

1. Bevilacqua JL, Kattan MW, Changhong Y, Koifman S, Mattos IE, et al. (2012) Nomograms for predicting the risk if arm lymphedema after axillary dissection in breast câncer. Ann Surg Oncol 19(8): 2580-2589.

2. Smile TD, Tendulkar R, Schwarz G, Arthur D, Grobmyer S, et al. (2018) A review of treatment for breast cancer-related lymphedema: paradigms for clinical practice. Am J Clin Oncol 41(2): 178-190. 
3. Marx AG, Figueira, PVG (2013) Fosopterapia no câncer de mama. In: Manole, Ridner SH (Eds.), 1a edição, Pathophysiology of lymphedema, São Paulo, Brazil. Semin Oncol Nurs 29(1): 4-11.

4. Olszewski W (2009) Anatomical distribution of tissue fluid and lymph in soft tissues of lower limbs in obstructive lymphedema-hints for physiotherapy. Phlebolymphology 16: 283-289.
5. Cui L, Zhang J, Zhang X, Chang H, Qu C, et al. (2015) Angiosarcoma (stewart-treves syndrome) in postmastectomy patients: report of 10 cases and review of literature. Int J Clin Exp Pathol 8(9): 11108-11115.

6. Alan S, Aktas H, Ersoy ÖF, Akt men A, Erol H (2016) Stewart treves syndrome in a woman with mastectomy. J Clin Diagn Res 10(2): WD01-WD02.
Creative Commons Attribution 4.0 International License

For possible submissions Click Here
Submit Article

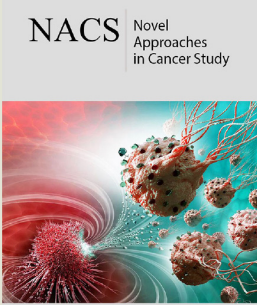

\section{Novel Approaches in Cancer Study \\ Benefits of Publishing with us}

- High-level peer review and editorial services

- Freely accessible online immediately upon publication

- Authors retain the copyright to their work

- Licensing it under a Creative Commons license

- Visibility through different online platforms 